\title{
Cytopathologic Diagnosis in Pleural Effusion and Cyto-Histopathologic Correlation
}

\section{Plevral Efüzyonda Sitopatolojik Tanı ve Sito-Histopatolojik Korelasyon}

\author{
Adile Ferda DAĞLI, Şirin KÜçÜK, Müge SEZER, Özlem ÜÇER \\ Department of Pathology, FIrat University, Faculty of Medicine, ELAZIĞ, TURKEY
}

\begin{abstract}
Objective: Cytological examination of pleural fluids is a fast, efficient and non-invasive diagnostic method. Identification of malignant effusions bears critical importance in treatment and prognosis. The aim of this study was to investigate the distribution of cytopathologic diagnoses in pleural effusions and the cyto-histopathologic correlation rates.
\end{abstract}

Material and Method: A total of 298 pleural fluid cases diagnosed from 2008 to 2009 in our laboratory were retrospectively identified as the study group. Evaluation results were classified in 5 groups as inconclusive, benign, atypical, suspicious and malignant, and compared with the biopsy results.

Results: Of the total 298 pleural fluid cases, 114 (38.3\%) were females and $184(61.7 \%)$ were males. The age range was between 15 and 89 with a mean value of $58.4 \pm 17.8$. Of the cases, $3(1 \%)$ were diagnosed as inadequate, $246(82.6 \%)$ benign, 8 atypical, 10 suspicious, and 31 malignant by cytology. Among the cases who were diagnosed as malignant, $24(8.1 \%)$ were reported as metastatic carcinoma and $7(2.3 \%)$ as malignant mesothelioma. Of the 8 cases reported as atypical, biopsy results of 2 showed malignant mesothelioma, and of the 10 cases reported as suspicious, 1 case whose biopsy result was obtained was diagnosed as epidermoid carcinoma metastasis.

Conclusion: Cytological examination is the most valuable diagnostic method for pleural effusions which may have various etiological causes. The most common cause of pleural effusions in our region is metastatic carcinomas including those from the lung, breast and ovarian tumors, followed by malignant mesothelioma.

Key Words: Pleural effusion, Cytopathology, Histopathology
ÖZ

Amaç: Plevral sıvıların sitolojik incelemesi tanı koymada hızlı, etkili noninvaziv bir yöntemdir. Malign efüzyonların saptanması tedavi ve prognoz açısından önem taşımaktadır. Bu çalışmanın amacı, plevral efüzyonlarda sitopatolojik tanı dağılımı ve sito-histopatolojik korelasyon oranını araştırmaktır.

Gereç ve Yöntem: Laboratuvarımızda retrospektif olarak 20082009 yılları arasında tanı alan 298 plevral sıvı olgusu çalışma grubu olarak belirlendi. Değerlendirme sonuçları yetersiz, benign, atipik, kuşkulu ve malign şeklinde beş gruba ayrılarak biyopsi sonuçlarıyla karşılaştırıldı.

Bulgular: Toplam 298 plevral sıvı olgusunun 114'ü $(\% 38,3)$ kadın, 184'ü (\%61,7) erkekti. Yaş aralığı 15-89 olup, genel ortalama $58,4 \pm 17,8$ 'di. Sitolojide olguların 3'üne (\%1) yetersiz, 246'sına $(\% 8,26)$ benign, 8 'ine atipik $(\% 2,7), 10$ 'una $(\% 3,4)$ kuşkulu ve 31 'ine $(\% 10,4)$ malign tanısı verildi. Malign tanısı alan olguların 24 ü $(\% 8,1)$ metastatik karsinom, 7'si (\%2,3) malign mezotelyoma olarak rapor edildi. Atipik olarak rapor edilen 8 olgudan biyosisi gelen 2 olguya malign mezotelyoma tanısı verilirken, kuşkulu olarak rapor edilen 10 olgudan biyopsisi gelen 1 olgu epidermoid karsinom metastazı tanısı ald.

Sonuç: Plevral efüzyonlar için sitolojik inceleme en değerli tanı yöntemi olup, etiyolojik nedenleri farklılıklar göstermektedir. Bölgemizde en sık malign plevral efüzyon nedeni akciğer, meme ve over tümörleri başta olmak üzere metastatik karsinomlar olup, ikinci sirada malign mezotelyoma gelmektedir.

Anahtar Sözcükler: Plevral efüzyon, Sitopatoloji, Histopatoloji

\section{INTRODUCTION}

The pleura is a serous membrane that lines the lungs, diaphragm and thoracic cavity. It is divided into the parietal and visceral pleura. The pleural fluid is found as a thin layer between the two pleural layers and keeps the pleural surfaces sliding over each other during respiration $(1,2)$.
Pleural effusion is the excessive collection of fluid in the pleural space due to lung disease or systemic disorders. It can reflect systemic problems as disorders of any system or organ can affect the pleura (3-5). Pleural effusion is frequent and easy to detect but it is not possible to always determine the etiology. The cytological investigation of pleural fluids 
is therefore a rapid, effective and noninvasive method to determine the etiology $(6,7)$.

Although parapneumonic effusions take first place in the etiology of exudative pleural effusions, malignant effusions are seen to be the most common when fluids that require thoracentesis are taken into account. Lung and breast cancers are the most common cause of malignant pleural effusions. The first evaluation of patients with lung cancer reveals malignant pleural effusion at rate of approximately 15\% (5).

The presence of malignant effusion is of great importance regarding the treatment and prognosis. For example, the presence of malignant effusion in lung cancer eliminates the possibility of surgical treatment while it is a sign of

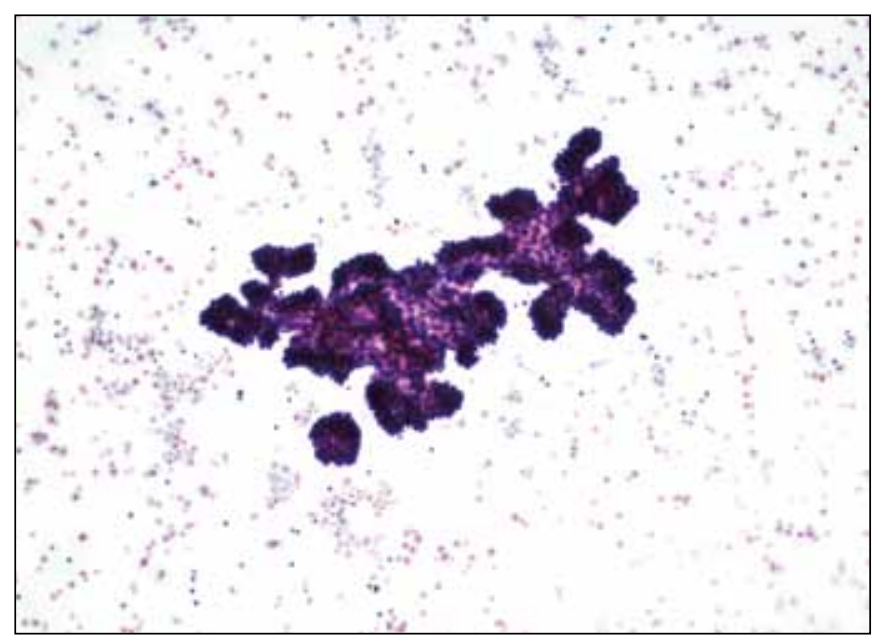

Figure 1: Microscopic appearance of metastatic carcinoma in the pleural fluid with a primary in the ovary (Pap; $x 100)$.

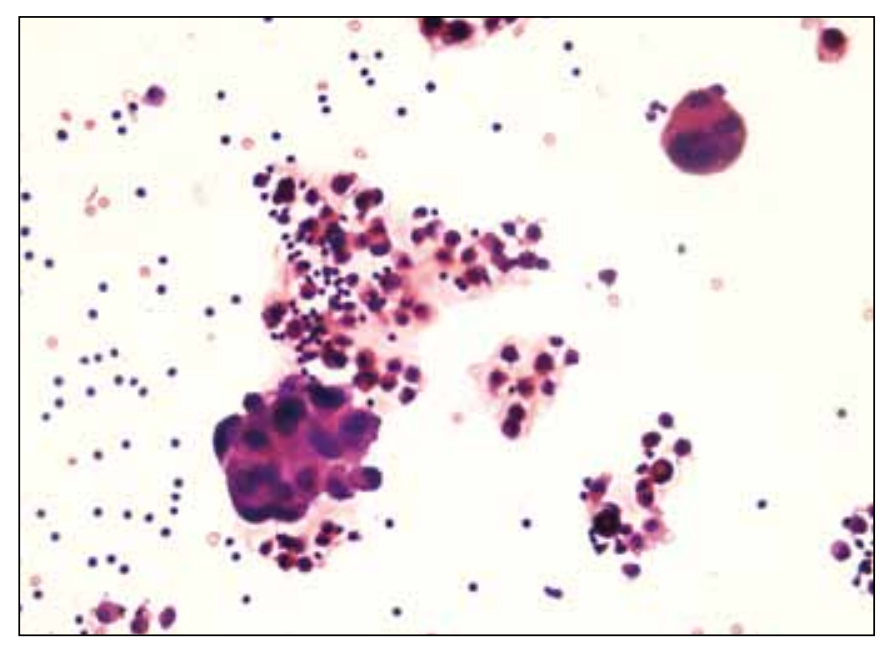

Figure 3: Microscopic appearance of malignant mesothelioma in the pleural fluid (Pap; $\mathrm{x} 400$ ). advanced disease and short survival in tumors of other organs (8).

Cytopathologic investigation is known to have a high diagnostic value in malignant pleural effusions (6,9-11). We therefore investigated the distribution of cytopathologic diagnoses and the cyto-histopathologic correlation rates in this study.

\section{MATERIAL and METHOD}

A total of 298 cases with pleural effusion that had been diagnosed in our laboratory between 2008 and 2009 were retrospectively evaluated an included in the study. The diagnoses obtained previously from direct smear of the fluid were reviewed. The evaluation results were divided into five groups as inadequate, benign, atypical, suspect, and malignant and compared to the biopsy results.

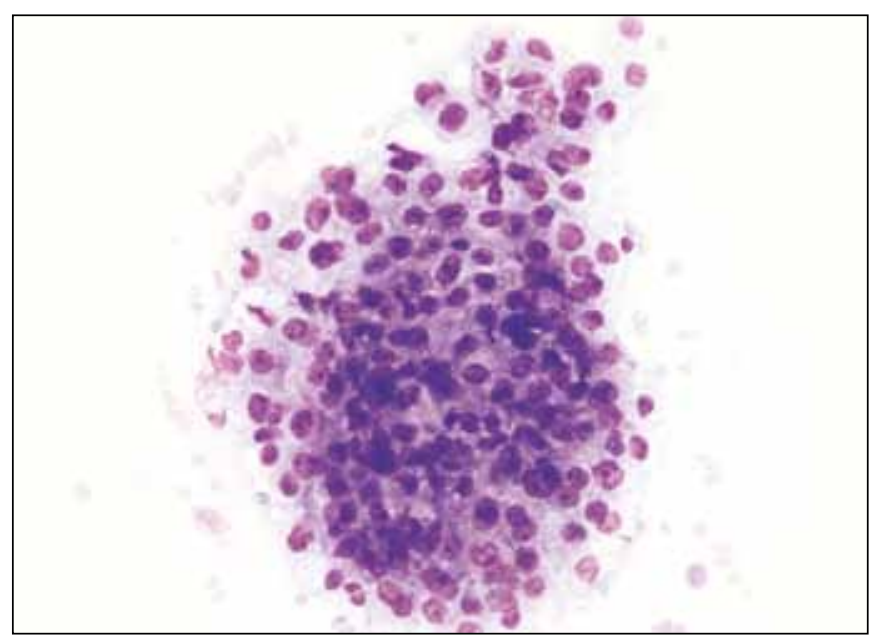

Figure 2: Microscopic appearance of metastatic carcinoma in the pleural fluid with a primary in the breast (MGG; $x 400)$.

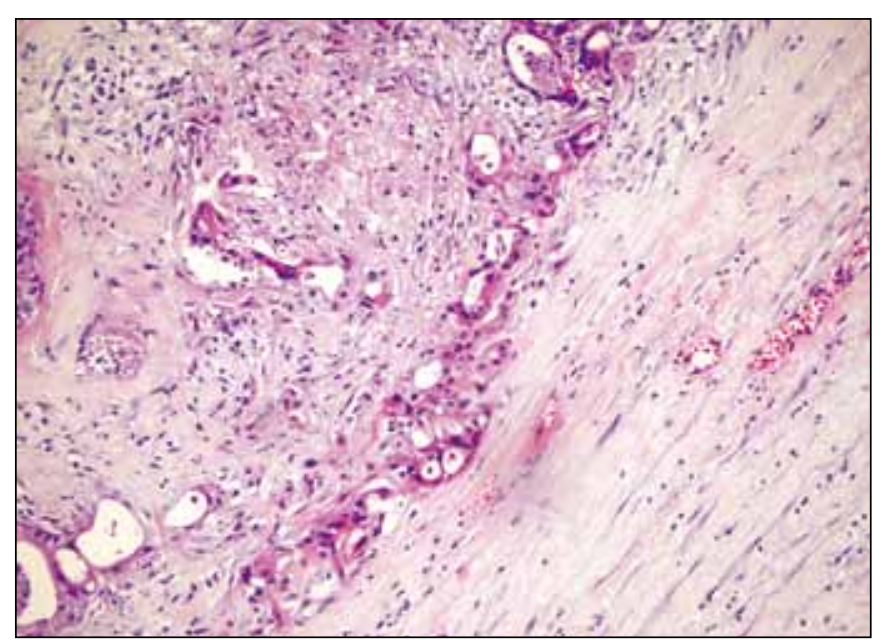

Figure 4: Microscopic appearance of metastatic primary lung adenocarcinoma in the pleural biopsy (H\&E; x400). 


\section{RESULTS}

The 298 pleural fluid cases consisted of 114 (38.3\%) females and $184(61.7 \%)$ males (Table I). The age range was 15-89 with a mean value of $58.4 \pm 17.8$. The cytology diagnoses were inadequate in $3(1 \%)$ because of acellularity, benign in $246(82.6 \%)$, atypical in $8(2.7 \%)$, suspicious in 10 $(3.4 \%)$ and malignant in $31(10.4 \%)$ (Table II). Immunohistochemical methods were used for the differential diagnosis in cases that received a malignant diagnosis. Cases that received a diagnosis of atypical did not have as many cells as the suspicious and malignant groups and contained cells with increased nucleus to cyoptlasm ratio, relatively regular nuclear membranes and showing mild atypia while cases reported as suspicious were as cellular as malignancies, had nuclear membrane irregularity but the cell atypia and number of mitoses were not as marked as in malignancies. The report for $24(8.1 \%)$ of the cases reported as malignant was metastatic carcinoma (Figure $1,2)$ while $7(2.3 \%)$ had malignant mesothelioma (Figure 3 ) (Table III). Four of the 7 cases that received a diagnosis of malignant mesothelioma and had a biopsy were confirmed histopathologically as well. Of the 24 cases with a diagnosis of metastatic carcinoma, 6 had a pleural biopsy and the diagnosis was ovarian carcinoma metastasis in 2, pleural liposarcoma in 1, pulmonary adenocarcinoma metastasis in 2 (Figure 4) and malignant epithelial tumor metastasis in 1 . Of the 18 cases diagnosed with metastatic carcinoma who did not have a biopsy, the history was consistent with pulmonary adenocarcinoma in 5 , breast carcinoma in 5 ,

Table I: Gender distribution of pleural cytology cases

\begin{tabular}{|l|c|c|c|}
\hline & Female (\%) & Male (\%) & Total \\
\hline Pleural fluid cytology & $114(38,3)$ & $184(61,7)$ & 298 \\
\hline
\end{tabular}

tumor of unknown primary in 4, ovarian carcinoma in 3 and gastric adenoendocrine carcinoma in 1 (Table IV). The diagnosis was malignant mesothelioma in the 2 cases that had a biopsy out of the 8 cases reported as atypical while only 1 case of the 10 suspicious cases received a diagnosis of epidermoid carcinoma metastasis due to inadequate clinical follow-up and patient compliance.

\section{DISCUSSION}

Pleural effusion is a common complication of many disorders (12). The first step in evaluating pleural fluids is determining the transudate and exudate features. Transudates are clear fluids with a low protein content and a glucose content similar to serum and are produced in disorders that cause increased hydrostatic pressure or decreased oncotic pressure. They do not contribute to the determination of the etiology in these cases as the pleural surface is normal. Exudates are slightly hazy fluids with a high protein content and low glucose level and are produced in conditions where the pleural pressure and lymphatic flow decreases and the pleural protein permeability increases. A thick needle biopsy is rapid and reliable in determining the etiology in such cases $(6,13,14)$.

The etiology of pleural effusion varies by region (15). It has been reported that the etiology cannot be elucidated in up to $20 \%$ of the cases as pleural effusion can be caused by many diseases $(16,17)$. Non-malignant causes such as pneumonia, heart failure and liver disease are found in $80 \%$ of the cases while malignancy-related reasons make up the remaining $20 \%$ (12). Gönlügür et al. (15) have found malignant mesothelioma to take first place among the causes of pleural effusion, followed by parapneumonic effusions, tuberculous pleurisy and congestive heart failure. Malignant diseases are one of the most common causes other than tuberculosis of exudative pleural effusions $(4,18)$. A malignant pleural effusion is recognized by demonstrating malignant cells in the pleural fluid or pleural tissue biopsies. The effusion seen

Table II: Diagnostic subgroups for pleural fluid cytology

\begin{tabular}{|l|c|c|c|c|c|c|}
\hline & $\begin{array}{c}\text { Inadequate } \\
(\mathbf{1 \% )}\end{array}$ & $\begin{array}{c}\text { Benign } \\
\mathbf{( 8 2 . 6 \% )}\end{array}$ & $\begin{array}{c}\text { Atypical } \\
\mathbf{( 2 . 7 \% )}\end{array}$ & $\begin{array}{c}\text { Suspicious } \\
\mathbf{( 3 . 4 \% )}\end{array}$ & $\begin{array}{c}\text { Malignant } \\
\mathbf{( 1 0 . 4 \% )}\end{array}$ & Total \\
\hline Pleural fluid cytology & 3 & 246 & 8 & 10 & 31 & 298 \\
\hline
\end{tabular}

Table III: Tumor types comprising malignant pleural cytology

\begin{tabular}{|l|c|c|c|}
\hline & Metastatic carcinoma (\%) & Malignant mesothelioma (\%) & Total \\
\hline Malignant pleural cytology & $24(8,1)$ & $7(2,3)$ & 31 \\
\hline
\end{tabular}


Table IV: Distribution of metastatic carcinomas by tumor type (pleural biopsy present/absent)

\begin{tabular}{|c|c|c|c|c|c|c|c|c|c|c|}
\hline & \multicolumn{4}{|c|}{ Pleural biopsy present } & \multicolumn{5}{|c|}{ Pleural biopsy absent } & \multirow[t]{2}{*}{ Total } \\
\hline & $\begin{array}{c}\text { Ovarian } \\
\text { carcinoma } \\
\text { metastasis }\end{array}$ & $\begin{array}{c}\text { Pleural } \\
\text { liposarcoma }\end{array}$ & $\begin{array}{c}\text { Lung } \\
\text { adenocarsino- } \\
\text { ma metastasis }\end{array}$ & $\begin{array}{l}\text { Malignant } \\
\text { epithelial } \\
\text { tumor } \\
\text { metastasis }\end{array}$ & $\begin{array}{c}\text { Lung } \\
\text { adenocarci- } \\
\text { noma }\end{array}$ & $\begin{array}{c}\text { Breast } \\
\text { carcinoma }\end{array}$ & $\begin{array}{c}\text { Tumor of } \\
\text { unknown } \\
\text { primary }\end{array}$ & $\begin{array}{c}\text { Ovarian } \\
\text { carcinoma }\end{array}$ & $\begin{array}{l}\text { Gastric } \\
\text { adenoen- } \\
\text { docrine } \\
\text { carcinoma }\end{array}$ & \\
\hline $\begin{array}{l}\text { Metastatic } \\
\text { carcinoma }\end{array}$ & 2 & 1 & 2 & 1 & 5 & 5 & 4 & 3 & 1 & \\
\hline Total & \multicolumn{4}{|c|}{6} & \multicolumn{5}{|c|}{18} & 24 \\
\hline
\end{tabular}

in cases where the malignancy does not directly affect the pleura is called a premalignant effusion (19).

The most common mechanism of pleural effusion in patients with malignant disease is lymphatic obstruction $(4,19,20)$. The most common cause of malignant effusion in women is breast and ovary cancer metastasis while lung cancer and malignant mesothelioma affect both sexes equally (21). Bayrak et al. (22) have found lung cancer to take first place among causes of malignant pleural effusion, followed by breast cancer, mesothelioma and lymphoma. Although primary pleural malignancies are seen less commonly, the incidence of malignant mesothelioma is increased in areas with asbestos exposure (23). Arbak et al. (24) found primary lung carcinomas to take first place among malignancyassociated pleural effusion causes followed by tumors metastasizing to the pleura. Metastatic carcinomas took first place among the causes of malignant pleural effusion in our study and lung, breast and ovary tumors were the most common. The frequency of mesotheliomas, taking second place, was noteworthy. This may be due to the fact that our hospital serves the Elazığ province and surrounding areas that have a large number of persons exposed to asbestos. Özkara et al. (23) have found mesothelioma to take first place as the cause of malignant effusion in their study, followed by lung cancers.

It is not possible to find a primary cancer focus in $4.7 \%$ of patients with a malignant effusion (4). We found a tumor with unknown primary in 4 of the 18 cases diagnosed with a metastatic carcinoma and did not have a biopsy. The rate of malignant pleural effusion can reach $40-87 \%$ in different series on cytopathologic investigation. It is easy to diagnose adenocarcinoma with pleural cytology while diagnosing squamous cell carcinoma, Hodgkin's lymphoma and sarcoma is quite difficult (5). In our study, 24 of the 31 cases receiving a diagnosis of malignant on cytology were diagnosed as metastatic carcinoma and 7 of these were diagnosed as lung adenocarcinoma with 2 having and 5 not having a biopsy. One case was diagnosed as pleural liposarcoma.

The sensitivity of pleural tissue biopsy in the diagnosis of malignant pleurisy is lower than that of cytopathologic evaluation. Very few cases negative on cytology can be diagnosed by biopsy (5). The diagnosis was benign in 246 $(82.6 \%)$ of 298 pleural fluid cases in our study.

In conclusion, cytopathologic investigation for pleural fluid is fast, rapid, noninvasive and is very important regarding treatment and prognosis as it constitutes the primary diagnostic step. Although the etiology of pleural effusions vary, the most common causes of malignant pleural effusion in our country are metastatic carcinomas and especially lung, breast and ovary tumors. Malignant mesotheliomas take second place.

\section{REFERENCES}

1. Light RW, Macgregor MI, Luchsinger PC, Ball WC Jr: Pleural effusions: The diagnostic separation of transudates and exsudates. Ann Intern Med 1972, 77: 507-513

2. Loddenkemper R, Antony VB: Introduction. Eur Respir Mon 2002, 22: C

3. Light RW: Diagnostic approach in a patient with pleural effusion. Eur Respir Mon 2002, 22: 131-145

4. Marel M: Epidemiology of pleural effusions. Eur Respir Mon 2002, 22: 146-156

5. Light RW: Pleural diseases. 4th ed. Philadelphia, Lippincott Williams and Wilkins, 2001, 120-123

6. Polatlı M, Aysan T, Erdinç M, Günel Ö: Plevra sıvı sitolojisi ve plevra biyopsisinin tanı değeri. Tuberk Toraks 1997, 45: 12-15

7. Christopher DJ, Peter JV, Cherian AM: Blind pleural biopsy using a Tru-cut needle in moderate to large pleural effusion-an experience. Singapore Med J 1998, 39: 196-199

8. Uzunlar AK, Büyükbayram H, Kırbaş G, Yaldız M, Yılmaz F, Arslan A: Plevral sıvı sitolojisi ve biyopsisinin tanı değeri (Bir Retrospektif Çalışma). Solunum Hastalık 2000, 11: 169-173

9. Prakash UB, Reiman HM: Comparison of needle biopsy with cytologic analysis for the evaluation of pleural effusion: analysis of 414 cases. Mayo Clin Proc 1985, 60: 158-64 
10. Ardıç S, Artvinli M, Şahin AA, Özdemir N: Plevral effüzyonların tanısında tanı yöntemlerinin başarısı. Solunum 1987, 12: 594-604

11. Özesmi M, Tuncer M: Plörezide klinik yaklaşım. Solunum 1983, 8: $207-214$

12. Hackbarth JS, Murata K, Reilly WM, Algeciras-Schimnich A: Performance of CEA and CA19-9 in identifying pleural effusions caused by specific malignancies. Clin Biochem 2010, 43: 1051-1055

13. Tufan M, Polatlı M, Bayındır Ü: Plevra sivisı ve serumda bilirubin konsantrasyonları ve albumin gradienti. Solunum 1991, 16: 510-515

14. Adams VI, Unni KK, Muhm RJ, Jett JR, Ilstrup DM, Bernatz PE: Diffuse malignant mesotelioma of pleura. Diagnosis and survival in 92 cases. Cancer 1986, 58: 1540-1551

15. Gönlügür TE, Gönlügür U: 454 Plevral efüzyonun retrospektif analizi. İnönü Üniv Tip Fak Derg 2007, 14: 21-25

16. Storey DD, Dines DE, Coles DT: Pleural effusion: a diagnostic dilemma. JAMA 1976, 236: 2183-2186

17. Hirsch A, Ruffie P, Nebut M, Bignon J, Chrétien J: Pleural effusion: Laboratory test in 300 cases. Thorax 1979, 34: 106-112
18. Porcel JM, Aleman C, Bielsa S, Sarrapio J, Fernandez de Sevilla T, Esquerda A: A decision tree for differentiating tuberculous from malignant pleural effusions. Respir Med 2008, 102: 1159-1164

19. Sahn SA: Pleural diseases related to metastatic malignancies. Eur Respir J 1997, 10: 1907-1913

20. Sahn SA: Malignant pleural effusions. Eur Respir Mon 2002, 22: 177-188

21. Slipicevic A, Frode G, Askildt IC, Holth A, Hellesylt E, Florenes VA, Davidson B: Diagnostic and prognostic role of insulin growth factor pathway members insulin-like growth factor-II and insulin-like growth factor binding protein-3 in serous effusions. Hum Pathol 2009, 40: 527-537

22. Bayrak MG, Erkan L, Uzun O, Fındık S, Atıcı AG, Özkaya Ş: Plevral efüzyonlu 153 hastanın değerlendirilmesi. Solunum Hastalık 2006, 17: 66-67

23. Özkara Ş, Fırat S, Dinç M: Masif plevral effüzyonların görülme sıklığ1 ve etiyolojileri. Solunum 1996, 12: 423-428

24. Arbak P, Karacan Ö, Erden F: A. Ü Tip Fakültesi Gögüs Hastalıkları kliniğinde 1990-1994 yılları arasında izlenen plevral sıvılı olguların özellikleri. Tuberk Toraks 1998, 46: 256-263 